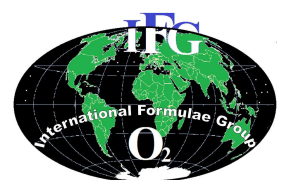

Available online at http://ajol.info/index.php/ijbcs

Int. J. Biol. Chem. Sci. 8(3): 1308-1318, June 2014

International Journal

of Biological and

Chemical Sciences

ISSN 1997-342X (Online), ISSN 1991-8631 (Print)

Original Paper

http://indexmedicus.afro.who.int

\title{
In ovo antiviral potency of the leaf constituents of Tanzanian Toussaintia species against Infectious Bursal Disease Virus and Newcastle Disease Virus
}

\author{
Stephen S. NYANDORO ${ }^{1 *}$, Mayunga H.H. NKUNYA ${ }^{1}$, Joseph C. COSAM ${ }^{1}$ and \\ Peter L.M. MSOFFE ${ }^{2}$ \\ ${ }^{I}$ Chemistry Department, College of Natural and Applied Sciences, University of Dar es Salaam, P.O. Box \\ 35061, Dar es Salaam, Tanzania. \\ ${ }^{2}$ Department of Veterinary Medicine and Public Health, Sokoine University of Agriculture, P.O. Box 3021, \\ Morogoro, Tanzania. \\ *Corresponding author; E-mail: samwel@chem.udsm.ac.tz; samnyandoro@yahoo.com; \\ Tel: +255 22 2410038; Mobile: (+255) 754 206560/718 944 724; Fax: + 255222410038
}

\begin{abstract}
The chemical constituents of Toussantia orientalis and T. patriciae (Annonaceae) leaf extracts were evaluated for their antiviral activities in ovo against Infectious Bursal Disease Virus (IBDV) and Newcastle Disease Virus (NDV). The nine-day-old embryonated eggs in a set of five were used for testing through the allantoic route inoculation assay for each tested compound and controls. For NDV assay, the allantoic fluids from the specimens were further harvested to determine viral contagion. The tested compounds exhibited potency with varying levels of significance at a screening concentration of $360 \mu \mathrm{g} / \mathrm{ml}$ against the two viral strains. Embryos infected with IBDV survived, grew to normal size with complete organ formation and had mean weights comparable to those of the uninfected ones when treated with the aminocinnamoyl tetraketides 1 , 2, and 4, glucosylflavonoid $\mathbf{7}$ from $T$. orientalis and ursolic acid derivatives $\mathbf{9}$ and $\mathbf{1 0}$ from $T$. patriciae demonstrating high efficacy against IBDV. The compounds also exhibited antiviral activity against NDV, showing viral titre reduction ranging from 1:16 - 1:256 in the haemagglutination test, with compound 11 having the lowest titre value (1:16) followed by compound 7 (1:32). The compounds that exhibited significant antiviral efficacy could be considered potential leads for the development of antiviral agents.

(C) 2014 International Formulae Group. All rights reserved.
\end{abstract}

Keywords: Aminocinnamoyl tetraketides, ursolic acids, Toussaintia orientalis, Toussaintia patriciae, Annonaceae.

\section{INTRODUCTION}

Poultry production in Tanzania and other low income countries is dominated by the free-range local chickens (FRLC) forming one of the major economic activities for majority of the people living in the rural areas. It has been established that rural poultry industry contributes significantly to improving income at household levels (Kisungwe et al., 2012; Moreki, 2013). The industry is characterized by low productivity arising from such constraints as diseases, predation, poor management and marketing strategies (Kisungwe et al., 2012). The major diseases affecting FRLC include the devastating Newcastle Disease (ND), Infectious Bursa 
Disease (IBD, Gumboro) among the viral diseases and fowl typhoid, callibacillosis among bacterial diseases (Moreki, 2013). Interventions towards control of these diseases have mostly involved the use of vaccines, which are practically inaccessible and expensive to the poor rural villagers. Hence, many people in the villages resort to the use of the cheap and easily available ethnoveterinary plants (Waihenya et al., 2002; Adejeji et al., 2013; Moreki, 2012; Moreki, 2013). The evidence and importance of plant-based natural products in the treatment and control of poultry viral diseases has been reported (Waihenya et al., 2002; Bakari et al., 2012; Bakari et al., 2013; Mabiki et al., 2013), calling for more research endeavors to the untapped biomedical potential of bioresources endowment of tropical and subtropical floral diversity.

In our recent papers, we reported the isolation of a series of novel bioactive aminocinnamoyl tetraketides (Samwel et al., 2011), a new glucosylglycero- $N$-octenyl adipate and a known glycoflavonoid afzelin from the leaf extracts (Nyandoro el al., 2012) of the red-listed endangered medicinal plant Toussiantia orientalis Verdc. (EAM-CFCEPF-PAP, 2009), several aristolactams, a pseudo-nucleoside 1-(2-C-methyl- $\beta$-Dribofuranosyl)-uracil and other bioactive metabolites from the stem and root bark extracts of the same plant species (Odalo et al., 2010). These results inspired us to include the recently described and red-listed endangered Toussaintia species, namely Toussaintia patriciae Q. Luke \& Deroin (Deroin and Luke 2005) in the phytochemical investigations to supplement the existing chemical information on the constituents of the genus Toussaintia and to further assess effectiveness of the metabolites isolated there from on poultry viruses. In the analysis, the leaf extracts of $T$. patriciae did not yield any of the metabolites that were previously obtained from $T$. orientalis, instead ursolic acids and ethyl gallate were obtained. The metabolites from $T$. patriciae together with the recently reported aminocynnamoyl tetraketides from $T$. orientalis were evaluated for their in ovo antiviral activity against the two poultry viruses; the Infectious Bursal Disease Virus (IBDV) and Newcastle Disease Virus (NDV) that are economically important to the poultry industry in many countries, Tanzania included.

\section{MATERIALS AND METHODS}

\section{Plant materials collection}

The leaves of Toussaintia patriciae Q. Luke \& Deroin were collected on $4^{\text {th }}$ June 2008 from Ndundulu Forest Reserve, 12 km from Udekwa Village, Kilolo District in Iringa Region, Tanzania. The plant species was authenticated at the Herbarium of the Department of Botany, University of Dar es Salaam where a voucher specimen is preserved (\# FMM 3521).

\section{Extraction, isolation and identification compounds}

The air-dried and powdered leaves (1.4 $\mathrm{kg}$ ) of $T$. patriciae were subjected to sequential extraction using petroleum ether, dichloromethane $\left(\mathrm{CH}_{2} \mathrm{Cl}_{2}\right)$ and ethanol $\left(\mathrm{CH}_{3} \mathrm{CH}_{2} \mathrm{OH}\right.$, EtOH $)$ at room temperature, each soaking lasting for $48 \mathrm{~h}$ so as to obtain less, medium and polar constituents of the plant materials, respectively. Removal of residual solvent under reduced pressure in a rotavap furnished the crude extracts. The pet ether and $\mathrm{CH}_{2} \mathrm{Cl}_{2}$ extracts were obtained in small quantities which did not show any interesting spots on thin layer chromatography (TLC) [Precoated plates (Merck, Kieselgel 60 F254, $0.20 \mathrm{~mm}$ )]. Hence, the extracts were not analysed further. The EtOH extract was obtained as a dark green gelatinous material (18.2 g), whose TLC analysis showed one conspicuous UV positive spot and other three UV negative spots [UV/VIS (254 and $365 \mathrm{~nm}$ ) and anisaldehyde spray reagent/heat at $c a 110$ $\left.{ }^{\circ} \mathrm{C}\right]$. EtOH extract was subjected to a repeated chromatographic separation (Silica gel 60 (Merck 230-400 mesh, 10-100\% Ethylacetate (EtOAc)/pet ether gradient) followed by gel 
filtration (Sephadex $\quad$ LH-20, $\quad 1: 1$ $\mathrm{MeOH} / \mathrm{CH}_{2} \mathrm{Cl}_{2}$ ) to isolate the compounds.

Chemical structures of the isolated compounds were identified upon analysis of their spectroscopic $\left[{ }^{1} \mathrm{H}-(300 \mathrm{MHz})\right.$ and ${ }^{13} \mathrm{C}$ NMR (75 MHz): Bruker Topspin Spectrometer and $\mathrm{CD}_{3} \mathrm{OD}$ or DMSO- $d_{6}$ as deuterated solvent, TMS as internal standard for ${ }^{1} \mathrm{H}$-NMR and solvent signal for ${ }^{13} \mathrm{C}-\mathrm{NMR}$ ] and spectrometric data [high-resolution electron ionisation mass spectra (HREIMS): GCT Premier TOF mass spectrometer, $70 \mathrm{eV}$ and $180{ }^{\circ} \mathrm{C}$ source temperature].

\section{In ovo antiviral assays}

Allantoic cavity inoculation assay

The embryonated eggs collected from healthy flocks were used for the determination of antiviral activity of the isolated natural products against IBDV (KMRG-48 strain) and velogenic NDV strain (13C/SUA). Both viral strains used in the experiment were supplied by the Department of Microbiology and Parasitology, Sokoine University of Agriculture and they originated from field outbreaks. The exterior surface of fertilized eggs were sterilized with $70 \%$ ethanol and incubated for 9 days at $37{ }^{\circ} \mathrm{C}$ and $65-70 \%$ humidity in an egg incubator (Memmert 854, Schwabach, Germany) prior to inoculation. The nine-day-old embryonated eggs were used for the antiviral testing through the allantoic cavity route of inoculation (Hsiung 1973). The eggs were candled to confirm their fertility and a small puncture was made through the shell over the air sac as previously described by Grimes (2002). The stock solutions containing the tested compounds were prepared by dissolving each sample (2 $\mathrm{mg}$ ) in dimethylsulphoxide (DMSO, $5 \mathrm{ml}$ ) to make a solution of $0.4 \mathrm{mg} / \mathrm{ml}$ concentration. The tested compounds were mixed with the viral strains and allowed to equilibrate for 30 min. before inoculation. The eggs were inoculated with the specimen $[0.1 \mathrm{~mL}$, having been prepared by mixing tested compound $(0.9 \mathrm{ml})$ with the viral strain $(0.1 \mathrm{ml})$ in allantoic fluid treated with the antibiotic
Gentamycin to make up a concentration of $360 \mu \mathrm{g} / \mathrm{ml}$ of the tested sample], using a sterile insulin needle and syringe. The inoculated site of the shell was sealed with paraffin wax and each egg was dated and labeled. For each set of the tested compound, five eggs were used per specimen (compound + virus), and three sets of controls were employed [egg control (eggs without any inoculums) acting as a negative control, solvent control (DMSO + virus) and virus control (virus only) acting as a positive control. The eggs were then incubated at 37 ${ }^{\circ} \mathrm{C}$ and $65-70 \%$ humidity for 72 and $96 \mathrm{~h}$ for IBDV and NDV, respectively.

The eggs were candled after every $24 \mathrm{~h}$ to monitor embryonic development and survival. The egg shells were then opened after 72 or $96 \mathrm{~h}$ of incubation to record mortality, survival, embryo size, weight, and organ formation. The specimen treated embryos were then compared and contrasted with the control sets in relation to survival, embryo size, weight, and completeness in tissue/organ formation. Furthermore, InStat 3 statistical package was used to compare the logarithm of the mean weight of the egg control (negative control) with those of the untreated virus-infected-embryos (positive control) and the treated embryos (compound + virus).

\section{Viral haemagglutination inhibition test}

In case of NDV assay, the allantoic fluid from the sample treated specimens and control eggs were further harvested to determine viral infectivity. The haemagglutination inhibition test was carried out as previously described by Allan and Gough (1974). A phosphate buffer solution (PBS, $25 \mu \mathrm{L}$ ) was placed in each well of the microtitre plate. Then allantoic fluids (25 $\mu \mathrm{L}$ each) from negative and positive controls and treated specimens (virus + tested compound) were added to the $1^{\text {st }}$ well of column 1, and each thoroughly mixed. A two fold serial dilution was done by transferring $25 \mu \mathrm{l}$ of the suspension to the next well and the last one discarded. The $25 \mu \mathrm{l}$ of $1 \%$ chicken RBCs in $99 \%$ PBS was added to each 
well of the microtitre plate. The microtitre plate was shaken, covered and incubated at room temperature for about $30 \mathrm{~min}$. The results were observed to see whether there was haemagglutination or not, and the lowest titre values were recorded at the end point beyond which there was no further haemagglutination.

IBDV being inactive in haemaglutination inhibition test and having no other test kits available at our exposal to quantitate IBDV antibodies during the investigation reported hereby, no attempt was made to establish the presence of IBDV following infection of the embryos.

\section{RESULTS}

\section{Isolation and identification of compounds}

Isolation and structural elucidation for compounds 1-7 (Figure 1) from T. orientalis is reported in our recent papers (Samwel et al., 2011; Nyandoro et al., 2012). Repeated chromatography of the leaf ethanol extract of Toussaintia patriciae yielded ursolic acid (8) (Budzikiewicz et al., 1963; Seebacher et al., 2003), its hydroxyl derivatives 30hydroxyursolic acid (9) (Budzikiewicz et al., 1963; Talapatra et al., 1981; Woo et al., 1984) and 19 $\alpha, 23$-dihydroxyursolic acid (10) (Budzikiewicz et al., 1963; Soares et al., 1998), together with ethyl gallate (ethyl 3,4,5trihydroxybenzoate, 11) (Ooshiro et al., 2009) (Figure 2). Structures of the isolated compounds were established based on analysis of both $1 \& 2 \mathrm{D}$ spectroscopic as well as spectrometric data, which were consistent with those reported in the literature.

\section{In ovo antivirial activity}

When evaluated for the in ovo antiviral activity at a concentration of $360 \mu \mathrm{g} / \mathrm{ml}$, the compounds demonstrated effective control of viral virulence at different levels of significance, with the nitrogenous compounds and and the glycosylflavonoid $\mathbf{7}$ isolated from T. orientalis exhibiting significant antiviral activity. These compounds effectively controlled the IBDV activity and enabled the embryo to grow to normal size with complete organ formation (Table 1). The mean weights of chicken embryos treated with each of these compounds showed no significance difference when compared with the mean weights of uninfected embryos (Table 2). However, compounds $\mathbf{3}, \mathbf{5}$ and $\mathbf{6}$, also isolated from $T$. orientalis showed insignificant activity against IBDV, with compound 6 being the least active. Furthermore, compounds 1-7 demonstrated antiviral activity against NDV by enabling the treated chicken embryos to grow to normal size and to complete organ formation (Table 3). However, the mean weights of embryos treated with each of these compounds against NDV were either very or highly significant compared to uninfected ones, indicating that the treatment was less effective (Table 4).

The ursane-type triterpenoids $\mathbf{8 - 1 0}$ as well as ethyl gallate (11) isolated from $T$. patriciae also showed high antiviral potency against IBDV. Thus, while the untreated chicken embryos died within $24 \mathrm{~h}$ of inoculation, the embryos treated with compounds 8-11 survived, and grew to normal size with complete organ formation similar to the uninfected embryos (Table 5). Compounds 9 and 10 were particularly effective against IBDV, with the mean weights being comparable to those of uninfected embryos, indicating effectiveness of the treatment (Table 6). Although compounds 8-11 also exhibited antiviral activity against NDV by enabling the treated chicken embryos to grow to normal size and to complete organ formation (Table 7), the difference in the mean weights of embryos treated with these compounds compared to the uninfected ones ranged from very to highly significant (Table 8 ), which meant that the treatment was less effective against this virus.

The haemagglutination inhibition test for NDV was used as an alternative method to evaluate the antiviral effect of the isolated compounds by generating viral titre values, which showed the extent to which the virus 
was cleared after treatment. The results from the haemagglutination test as were observed in the microtitre plate assays are represented in Table 9. Thus, on the basis of viral titre reduction, ethyl gallate (11) had the lowest titre value (1:16) followed by glycosylflavonoid 7 (1:32), while the other compounds had viral titre values of 1:128 and 1:256. These values were by far lower $(128$, 64,16 , or 8 times, respectively) than for the positive control (1:2048), indicating effectiveness of the compounds against NDV.

Table 1: Antiviral activity (at $360 \mu \mathrm{g} / \mathrm{ml}$ ) of compounds from Toussaintia orientalis against IBDV.

\begin{tabular}{|c|c|c|c|c|c|c|c|c|}
\hline & $\begin{array}{c}\text { Egg } \\
1\end{array}$ & $\begin{array}{c}\text { Egg } \\
2\end{array}$ & $\begin{array}{c}\text { Egg } \\
3\end{array}$ & $\begin{array}{c}\text { Egg } \\
4\end{array}$ & $\begin{array}{c}\text { Egg } \\
5\end{array}$ & $\begin{array}{c}\text { Embryo } \\
\text { size }\end{array}$ & $\begin{array}{c}\text { Embryo } \\
\text { average } \\
\text { weight }(\mathrm{g})\end{array}$ & $\begin{array}{c}\text { Embryo } \\
\text { organ } \\
\text { formation }\end{array}$ \\
\hline $\begin{array}{l}\text { Negative control } \\
\text { (Eggs without } \\
\text { any inoculums) }\end{array}$ & Alive & Alive & Alive & Alive & Alive & Normal & 7.626 & Complete \\
\hline $\begin{array}{l}\text { Solvent control } \\
\text { (Virus +DMSO) }\end{array}$ & Dead & Dead & Dead & Dead & Dead & Abnormal & 1.670 & Incomplete \\
\hline $\begin{array}{l}\text { Positive control } \\
\text { (Virus alone) }\end{array}$ & Dead & Dead & Dead & Dead & Dead & Abnormal & 1.647 & Incomplete \\
\hline Virus +1 & Alive & Alive & Alive & Alive & Alive & Normal & 6.939 & Complete \\
\hline Virus +2 & Alive & Alive & Alive & Alive & Dead & Normal & 6.921 & Complete \\
\hline Virus $+\mathbf{3}$ & Alive & Alive & Alive & Alive & Alive & Normal & 7.309 & Complete \\
\hline Virus +4 & Alive & Alive & Alive & Dead & Alive & Normal & 6.908 & Complete \\
\hline Virus +5 & Alive & Alive & Alive & Alive & Alive & Normal & 6.564 & Complete \\
\hline Virus +6 & Dead & Dead & Dead & Dead & Dead & Abnormal & 2.464 & Incomplete \\
\hline Virus +7 & Alive & Alive & Alive & Alive & Alive & Normal & 7.720 & Complete \\
\hline
\end{tabular}

Table 2: Comparison of the logarithm of the mean weight of untreated (infected with IBDV), treated (with compounds from Toussaintia orientalis) against uninfected embryos (Mean \pm SEM = $0.882 \pm 0.004)$.

\begin{tabular}{lccccc}
\hline Treatment & Mean \pm SEM & T-value & P-value & 95 \% CL & Comment \\
\hline IBDV only & $0.215 \pm 0.020$ & 32.512 & $<0.0001$ & $0.159-0.270$ & Highly significant \\
Virus + 1 & $0.837 \pm 0.033$ & 1.386 & 0.1015 & $0.745-0.927$ & Not significant \\
Virus + 2 & $0.837 \pm 0.026$ & 1.679 & 0.0659 & $0.076-0.911$ & Not significant \\
Virus + 3 & $0.845 \pm 0.011$ & 3.079 & 0.0076 & $0.814-0.876$ & Very significant \\
Virus + 4 & $0.862 \pm 0.022$ & 0.8993 & 0.1974 & $0.799-0.924$ & Not significant \\
Virus + 5 & $0.813 \pm 0.003$ & 12.565 & $<0.0001$ & $0.805-0.823$ & Highly significant \\
Virus + 6 & $0.349 \pm 0.098$ & 5.436 & 0.0003 & $0.077-0.620$ & Highly significant \\
Virus + 7 & $0.887 \pm 0.008$ & 0.5415 & 0.3014 & $0.864-0.911$ & Not significant \\
\hline Note: Level of significance, $\alpha=0.05[$ Not significant $(\mathrm{p} \geq 0.05)$, significant $(\mathrm{p}<0.05)$, very significant $(\mathrm{p}<0.01)$, \\
highly significant $(\mathrm{p}<0.001)]$.
\end{tabular}


Table 3: Antiviral activity (at $360 \mu \mathrm{g} / \mathrm{ml}$ ) of compounds from Toussaintia orientalis against NDV.

\begin{tabular}{lllllllll}
\hline & Egg 1 & Egg 2 & Egg 3 & Egg 4 & Egg 5 & $\begin{array}{c}\text { Embryo } \\
\text { size }\end{array}$ & $\begin{array}{c}\text { Embryo } \\
\text { average } \\
\text { weight (g) }\end{array}$ & $\begin{array}{c}\text { Embryo organ } \\
\text { formation }\end{array}$ \\
\hline $\begin{array}{l}\text { Negative control } \\
\begin{array}{l}\text { (Eggs without any } \\
\text { inoculums) }\end{array}\end{array}$ & Alive & Alive & Alive & Alive & Alive & Normal & 9.438 & Complete \\
$\begin{array}{l}\text { Positive control } \\
\text { (Virus +DMSO) }\end{array}$ & Dead & Dead & Dead & Dead & Dead & Abnormal & 3.837 & Incomplete \\
$\begin{array}{l}\text { Positive control } \\
\text { (Virus alone) }\end{array}$ & Dead & Dead & Dead & Dead & Dead & Abnormal & 3.204 & Incomplete \\
Virus + 1 & Alive & Alive & Alive & Alive & Alive & Normal & 6.206 & Complete \\
Virus + 2 & Alive & Alive & Alive & Alive & Alive & Normal & 6.734 & Complete \\
Virus + 3 & Alive & Alive & Alive & Alive & Alive & Normal & 6.656 & Complete \\
Virus + 4 & Alive & Alive & Alive & Alive & Alive & Normal & 6.372 & Complete \\
Virus +5 & Alive & Alive & Alive & Alive & Alive & Normal & 6.227 & Complete \\
Virus + 6 & Alive & Alive & Alive & Alive & Alive & medium & 5.000 & Complete \\
Virus + 7 & Alive & Alive & Alive & Alive & Alive & Normal & 7.374 & Complete \\
\hline
\end{tabular}

Table 4: Comparison of the logarithm of the mean weight of untreated (infected with NDV), treated (with compounds from Toussaintia orientalis) against uninfected embryos (Mean $\pm \mathrm{SEM}=0.972 \pm$ 0.026).

\begin{tabular}{lccccc}
\hline Treatment & Mean \pm SEM & T-value & P-value & 95 \% CL & Comment \\
\hline NDV only & $0.505 \pm 0.015$ & 16.171 & $<0.0001$ & $0.463-0.546$ & Highly significant \\
Virus + 1 & $0.792 \pm 0.015$ & 6.003 & 0.0002 & $0.754-0.833$ & Highly significant \\
Virus + 2 & $0.827 \pm 0.013$ & 4.965 & 0.0006 & $0.792-0.863$ & Highly significant \\
Virus + 3 & $0.804 \pm 0.011$ & 5.919 & 0.0002 & $0.772-0.836$ & Highly significant \\
Virus + 4 & $0.822 \pm 0.013$ & 5.069 & 0.0005 & $0.784-0.861$ & Highly significant \\
Virus + 5 & $0.794 \pm 0.007$ & 6.611 & $<0.0001$ & $0.805-0.823$ & Highly significant \\
Virus + 6 & $0.699 \pm 0.005$ & 10.250 & $<0.0001$ & $0.684-0.714$ & Highly significant \\
Virus + 7 & $0.868 \pm 0.005$ & 3.934 & 0.0022 & $0.855-0.881$ & Very significant \\
\hline
\end{tabular}

Table 5: Antiviral activity (at $360 \mu \mathrm{g} / \mathrm{ml}$ ) of compounds from Toussaintia Patriciae against IBDV.

\begin{tabular}{llllllccc}
\hline & Egg 1 & Egg 2 & Egg 3 & Egg 4 & Egg 5 & $\begin{array}{c}\text { Embryo } \\
\text { size }\end{array}$ & $\begin{array}{c}\text { Embryo average } \\
\text { weight (g) }\end{array}$ & $\begin{array}{c}\text { Embryo organ } \\
\text { formation }\end{array}$ \\
\hline Virus + 8 & Alive & Alive & Dead & Alive & Alive & Normal & 8.418 & Complete \\
Virus + 9 & Alive & Alive & Alive & Alive & Alive & Normal & 7.971 & Complete \\
Virus + 10 & Dead & Alive & Alive & Alive & Alive & Normal & 7.159 & Complete \\
Virus +11 & Alive & Alive & Alive & Alive & Alive & Normal & 8.218 & Complete \\
\hline
\end{tabular}


Table 6: Comparison of the logarithm of the mean weight of untreated (infected with IBDV), treated (with compounds from Toussaintia patriciae) against uninfected embryos (Mean $\pm \mathrm{SEM}=$ $0.882 \pm 0.004)$.

\begin{tabular}{lccccc}
\hline Treatment & Mean \pm SEM & T-value & P-value & 95 \% CL & Comment \\
\hline IBDV only & $0.215 \pm 0.020$ & 30.618 & $<0.0001$ & $0.159-0.270$ & Highly significant \\
Virus + 8 & $0.924 \pm 0.015$ & 2.772 & 0.0121 & $0.884-0.965$ & Significant \\
Virus + 9 & $0.900 \pm 0.014$ & 1.229 & 0.1270 & $0.861-0.960$ & Not significant \\
Virus + 10 & $0.924 \pm 0.018$ & 1.562 & 0.0784 & $0.803-0.903$ & Not significant \\
Virus + 11 & $0.914 \pm 0.013$ & 2.273 & 0.0263 & $0.877-0.951$ & Significant \\
\hline
\end{tabular}

Table 7: Antiviral activity (at $360 \mu \mathrm{g} / \mathrm{ml}$ ) of compounds from Toussaintia patriciae against NDV.

\begin{tabular}{lcccccccc}
\hline & Egg 1 & Egg 2 & Egg 3 & Egg 4 & Egg 5 & $\begin{array}{c}\text { Embryo } \\
\text { size }\end{array}$ & $\begin{array}{c}\text { Embryo } \\
\text { average } \\
\text { weight (g) }\end{array}$ & $\begin{array}{c}\text { Embryo organ } \\
\text { formation }\end{array}$ \\
\hline Virus + 8 & Alive & Alive & Dead & Alive & Alive & Normal & 7.004 & Complete \\
Virus + 9 & Alive & Alive & Alive & Alive & Alive & Normal & 5.926 & Complete \\
Virus + 10 & Alive & Alive & Alive & Alive & Alive & Normal & 7.075 & Complete \\
Virus + 11 & Alive & Alive & Alive & Alive & Alive & Normal & 7.518 & Complete \\
\hline
\end{tabular}

Table 8: Comparison of the logarithm of the mean weight of untreated (infected with NDV), treated (with compounds from Toussaintia patriciae) against uninfected embryos (Mean $\pm \mathrm{SEM}=0.826 \pm$ 0.013).

\begin{tabular}{lccccc}
\hline Treatment & Mean \pm SEM & T-value & P-value & 95 \% CL & Comment \\
\hline NDV only & $0.505 \pm 0.015$ & 15.573 & $<0.0001$ & $0.463-0.546$ & Highly significant \\
Virus + 8 & $0.846 \pm 0.003$ & 4.831 & 0.0007 & $0.855-0.852$ & Highly significant \\
Virus + 9 & $0.827 \pm 0.013$ & 6.299 & 0.0001 & $0.720-0.822$ & Highly significant \\
Virus + 10 & $0.849 \pm 0.003$ & 4.662 & 0.0008 & $0.843-0.857$ & Highly significant \\
Virus + 11 & $0.876 \pm 0.004$ & 3.622 & 0.0034 & $0.864-0.888$ & Very significant \\
\hline
\end{tabular}

Table 9: NDV Haemagglutination assay results.

\begin{tabular}{|c|c|c|c|c|c|c|c|}
\hline Specimen & $+v e /-v e$ & $\begin{array}{c}\text { Well } \\
\#\end{array}$ & Titre & Specimen & +ve/-ve & Well \# & Titre \\
\hline $\begin{array}{l}\text { Negative control } \\
\text { (Eggs without any inoculums) }\end{array}$ & -ve & -ve & -ve & Virus +5 & $+\mathrm{ve}$ & 8 & $1: 256$ \\
\hline Positive control (NDV alone) & $+\mathrm{ve}$ & 11 & $1: 2048$ & Virus +6 & $+\mathrm{ve}$ & 8 & $1: 256$ \\
\hline Solvent control (NDV +DMSO) & $+\mathrm{ve}$ & 10 & $1: 1024$ & Virus +7 & $+\mathrm{ve}$ & 5 & $1: 32$ \\
\hline Virus +1 & $+\mathrm{ve}$ & 8 & $1: 256$ & Virus $+\mathbf{8}$ & $+\mathrm{ve}$ & 7 & 1:128 \\
\hline Virus +2 & $+\mathrm{ve}$ & 8 & $1: 256$ & Virus +9 & $+\mathrm{ve}$ & 8 & $1: 256$ \\
\hline Virus $+\mathbf{3}$ & $+\mathrm{ve}$ & 8 & $1: 256$ & Virus+ 10 & $+\mathrm{ve}$ & 7 & 1:128 \\
\hline Virus +4 & $+\mathrm{ve}$ & 8 & 1:256 & Virus +11 & $+\mathrm{ve}$ & 4 & $1: 16$ \\
\hline
\end{tabular}


<smiles>[R]C1C=C[C@]2(O)CC(P)N([P])C2C1</smiles>

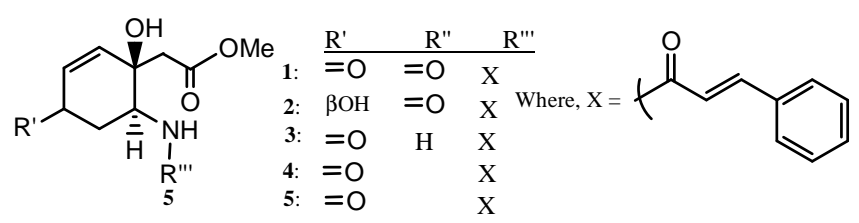

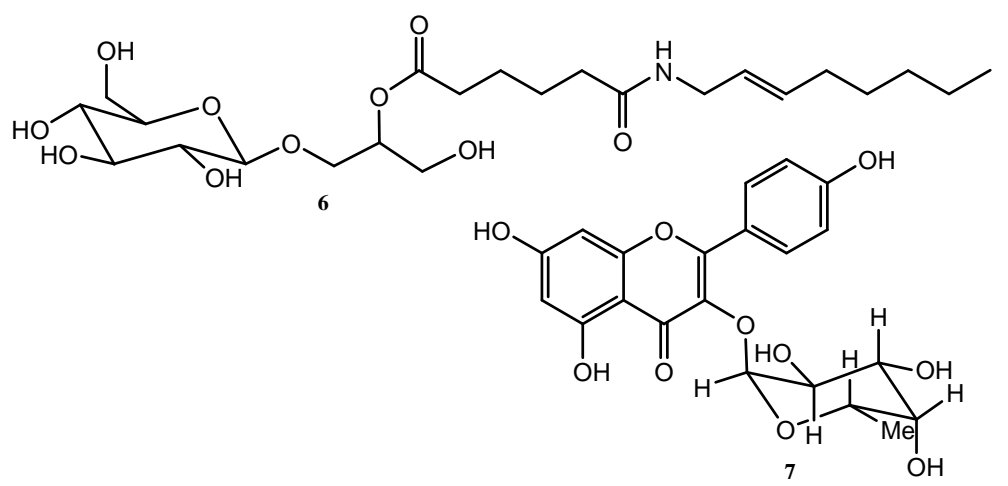

Figure 1: Compounds isolated from Toussaintia orientalis (1-7).

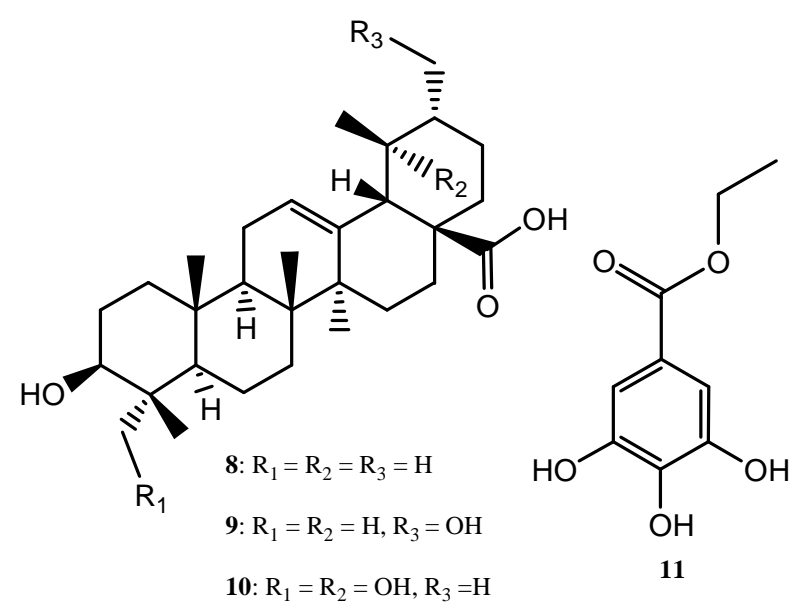

Figure 2: Compounds isolated from Toussaintiapatriciae (8-11).

\section{DISCUSSION}

The results of the antiviral assays as presented in these investigations have demonstrated the compounds isolated from
Toussantia orientalis and T. patriciae to have activity against the two tested avian viruses, albeit with unequal efficacy. Whereas the tetraketide nitrogenous compounds $\mathbf{1 , 2}$ and $\mathbf{4}$ 
and the glycosylflavonoid 7 isolated from $T$. orientalis, and ursolic acid derivatives 9 and 10 obtained from $T$. patriciae exhibited significant activity against IBDV, the other compounds showed moderate or weak activity. Generally, the tested compounds were more potent to IBDV than NDV. The observed differences in activity against the two assayed viruses and between the compounds tested could probably be attributed to structural differences hence the corresponding different modes of action of the compounds against the tested viruses. Thus, the compounds could have virucidal, inhibitory or combinations of both effects.

The nitrogenous compounds with nitrogen sandwiched between two carbonyl groups as in $\mathbf{1}$ and $\mathbf{2}$, or with electronegative oxygen and a carbonyl group as in $\mathbf{3}$ and $\mathbf{4}$ showed better activity than $\mathbf{5}$ that lacks a heterocyclic atom-containing fused ring. Such a structural-activity trend could be attributed to the variation in the degree of electrophilicity of the $N$-atom adjacent to electron withdrawing species (carbonyl group and oxygen), making the corresponding compounds to react at different rates with nucleophilic targets in the viral protein coat or nucleoside.

The triterpenoids $\mathbf{8}$ - $\mathbf{1 0}$ have some similarities in their structural features; that is, each has a hydroxyl group at C-3, a $\mathrm{C}_{12}-\mathrm{C}_{13}$ double bond and a carboxylic acid group at $\mathrm{C}$ 17. The compounds differ only in the extra hydroxylation at C-30 for 9, C-19 and C-23 for 10. Thus, the higher antiviral efficacy of compounds $\mathbf{9}$ and $\mathbf{1 0}$ as compared to $\mathbf{8}$ could have been due to the extra hydroxylation in the first two compounds. In fact, ursolic acid (8) and its derivatives similar to $\mathbf{9}$ and $\mathbf{1 0}$ are well known for their antiviral properties, which in most cases has been associated with the presence of an oxo- and hydroxylfunctionalities (Sun et al., 2006), as further corroborated in the present studies for the tested avian viral strains. On the other hand, alkyl gallates such as $\mathbf{1 1}$ are also known for their virucidal and inhibitory effects against viruses, particularly Herpes Simplex Virus (HSV). The previous structure activity relationship (SAR) studies of $n$-alkyl gallates indicated the three hydroxyl units and the alkyl group to play a role in the antiviral potency of such compounds (Kratz et al., 2008). Therefore, the same structural features could have also attributed to the observed antiviral activity of compound $\mathbf{1 1}$ reported in these investigations.

Although the viral load reduction and virulence control was evident as indicated by titre values (for NDV) and embryo survival, normal size, complete organ formation, and mean weights of chicken embryos treated with some compounds showing no significance difference as compared with uninfected embryos, the mode of action, elucidation of the exact target sites of the active compounds and their toxicity remains a subject of future research. Nevertheless, the in ovo antiviral results hereby reported indicate that the two Toussaintia species accumulate metabolites that are potential leads for the development of antiviral agents against IBDV and NDV. The results further underscore the need for the concerted efforts to conserve these bioresources vulnerable to extinction.

\section{ACKNOWLEDGEMENTS}

Financial support from Sida/SAREC is gratefully acknowledged. Mr. Frank M. Mbago, a curator at the Herbarium of the Department of Botany, University of Dar es Salaam for locating and identifying the investigated plant species. We also thank Mr. Jonas Fitwangile of Faculty of Veterinary Medicine, Sokoine University of Agriculture for his assistance during antiviral bioassay experiments. We are grateful to Prof. Runner 
T. Majinda of University of Botswana for facilitation of spectroscopic and spectrometric analyses of the compounds from T. patriciae.

\section{REFERENCES}

Adedeji OS, Ogunsina TK, Akinwumi AO, Ameen SA, Ojebiyi OO, Akinlade JA. 2013. Ethnoveterinary medicine in African organic poultry production. IFRJ, 20(2): 527-532.

Allan WH, Gough RE. 1974. A standard haemagglutination-inhibition test for Newcastle disease. A comparison of macro and micro methods. Vet. Rec., 95(6): 120-123.

Bakari GG, Max RA, Mdegela RH, Phiri ECJ, Mtambo MMA. 2012. Antiviral activity of crude extracts from Commiphora swynnertonii against Newcastle disease virus in ovo. Trop. Anim. Health Prod., 44(7): 1389-1393

Bakari GG, Max RA, Mdegela RH, Phiri ECJ, Mtambo MMA. 2013. Efficacy of resinous extract from Commiphora swynnertonii (Burrt) against Newcastle infection in chickens. Int. J. Med. Plants. Res., 2(2): 156-161.

Budzikiewicz H, Wilson JM, Djerassi C. 1963. Mass spectrometry in structural and stereochemical problems. Part XXXII. Pentacyclic triterpenes. Am. Chem. Soc., 85: 3688-3699.

Deroin T, Luke Q. 2005. A new Toussaintia (Annonaceae) from Tanzania. J. E. Afr. Nat. Hist., 94(1): 165-174.

EAM-CF-CEPF-PAP (Eastern Arc Mountains \& Coastal Forests CEPF Plant Assessment Project). 2009. Toussaintia orientalis. In IUCN 2013. IUCN Red List of Threatened Species. Version 2013.2. <www.iucnredlist.org>. Downloaded on 03 December 2013.

Grimes SE. 2002. A basic laboratory manual for the small-scale production and testing of I-2 Newcastle disease vaccine, Food and Agriculture Organization, RAP publications catalogue 2002-2003. Available from: http://www.fao.org/ docrep/005/ac802e/ac802e09.htm.

Downloaded 10/07/2009.

Hsiung GD. 1973. Diagnostic Virology: An Illustrative Handbook. Yale University Press: New Haven and London.

Kisungwe I, Giroud S, Kiranga H, Zuberi A. 2012. Transforming Traditional Poultry Keeping into a Commercial Venture: The Experience of RLDC with the Comprehensive Poultry Rearing Model. http://www.rldp.org/capex/poultrykeeping-capex. Downloaded 12/05/2014.

Kratz JM, Andrghetti-Frohne CR, Leal PC, Nunes RJ, Yunes RA, Trybala E, Bergstom T, Barardi CRM, Simoes CMO. 2008. Evaluation of anti-HSV-2 activity of gallic and pentyl gallate. Biol. Pharm. Bull., 31(5): 903-907.

Mabiki FP, Mdegela RH, Mosha RD, Magadula JJ. 2013. In ovo antiviral activity of Synadenium glaucescens (pax) crude extracts on Newcastle disease virus. J. Med. Plants Res., 7(14): 863-870.

Moreki JC. 2013. Documentation of ethnoveterinary practices used in family poultry in Botswana. Vet. World, 6(1): 18-21.

Moreki JC. 2012. Use of Ethnoveterinary Medicine in family poultry health management in Botswana: A review. $J$. Vet. Adv., 2(6): 254-260.

Nyandoro SS, Nkunya MHH, Joseph CC, Odalo JO, Sattler I. 2012. New glucopyranosylglycero- $N$-octenyl adipate and bioactivity of retro and condensed chalcones from Toussaintia orientalis. Tanz. J. Sci., 38(3): 108-126.

Odalo JO, Joseph CC, Nkunya MHH, Sattler I, Lange C, Friedrich G, Dahse H-M, Möllman U. 2010. Aristolactams, 1-(2-C- 
methyl-beta-D-ribofuranosyl)-uracil and other bioactive constituents of Toussaintia orientalis. Nat. Prod. Comm., 5(2): 253-258.

Ooshiro A, Hiradate S, Kawano S, Takushi T, Fujii Y, Natsume M, Abe H. 2009. Identification and activity of ethyl gallate as an antimicrobial compound produced by Geranium carolinianum. Weed Biol. Manag., 9(2): 169-172.

Samwel S, Odalo JO, Nkunya MHH, Joseph CC, Koorbanally NA. 2011. Toussaintines A-E: antimicrobial indolidinoids, a cinnamoylhydrobenzofuranoid and a cinnamoylcyclohexenoid from Toussaintia orientalis leaves. Phytochemistry, 72(14): 1826-1832.

Seebacher W, Simic N, Weis R, Saf R, Kunert O. 2003. Complete assignments of ${ }^{1} \mathrm{H}$ and ${ }^{13} \mathrm{C}$ NMR resonances of oleanolic acid, 18a-oleanolic acid, ursolic acid and their 11-oxo derivatives. Magn. Reson. Chem., 41(8): 636-638.
Soares FP, Ronconi CAV, da Cunha EVL, Barbosa-Filho JM, da Silva MS, BrazFilho R. 1998. Four known triterpenoids isolated from three Brazilian plants: ${ }^{1} \mathrm{H}$ and ${ }^{13} \mathrm{C}$ chemical shift assignments. Magn. Reson. Chem., 36(8): 608-614.

Sun H, Fang W-S, Wang W-Z, Hu C. 2006. Structure-activity relationships of oleanane- and ursane-type triterpenoids. Botanical Studies, 47(4): 339-368.

Talapatra SK, Sarkar AC, Talapatra B. 1981. Terpenoid and related compounds. Part XV111. Two pentacyclic triterpenes from Rubia cordifolia. Phytochemistry, 20(8): 1923-1927.

Waihenya RK, Mtambo MMA, Nkwengulila G, Minga UM. 2002. Efficacy of the crude extract of Aloe secundiflora in chickens experimentally infected with Newcastle disease virus. J. Ethnopharmacol., 79(3): 299-304.

Woo WS, Choi JS, Tovivich P. 1984. A sapogenin of Randia siamensis. Arch. Pharm. Res., 7(1): 57-60. 